\title{
Immunohistochemical expression of epidermal growth factor receptor (EGFR) in South Asian head and neck squamous cell carcinoma: association with various risk factors and clinico-pathologic and prognostic parameters
}

Atif Ali Hashmi', Zubaida Fida Hussain', Saher Aijaz², Muhammad Irfan', Erum Yousuf Khan' ${ }^{1}$ Samreen Naz' Naveen Faridi ${ }^{1}$, Amir Khan $^{3^{*}}$ (D) and Muhammad Muzzammil Edhi ${ }^{4}$

\begin{abstract}
Background: In this study, we intend to determine the immunohistochemical expression of EGFR in cases of head and neck squamous cell carcinoma and its association with prognostic clinico-pathologic features.

Methods: A total of 115 cases of head and neck squamous cell carcinoma treated at Liaquat National Hospital, Karachi, Pakistan, were included in the study. Clinico-pathologic features, risk factors, and recurrence status of cases were evaluated, and EGFR immunohistochemistry was performed.

Results: In our study, 52 cases (45.2\%) of head and neck SCC were positive and 10 cases (8.7\%) were focal positive for EGFR expression, while 53 cases (46.1\%) were negative for EGFR expression. High EGFR expression (> 70\%) was noted in $6.1 \%$ (7 cases), while 12.2\% (14 cases) and 26.1\% (30 cases) revealed $51-70 \%$ and $11-50 \%$ EGFR expression respectively. On the basis of intensity, strong EGFR expression was noted in 13.9\% (16 cases) while 16.5\% (19 cases) and 23.5\% (27 cases) revealed intermediate and weak EGFR expression respectively. Significant association of EGFR expression was noted with tumor stage and disease-free survival.

Conclusion: We found a significant association of EGFR expression with tumor stage and disease-free survivals, which are the most important prognostic factors in head and neck squamous cell carcinoma; therefore, EGFR expression can help as a prognostic biomarker in head and neck squamous cell carcinoma. On the other hand, we suggest that molecular studies should be performed in squamous cell carcinoma of head and neck in our setup to identify patients that can avail response from anti-EGFR therapy.
\end{abstract}

Keywords: Epidermal growth factor receptor, Head and neck squamous cell carcinoma, Oropharyngeal squamous cell carcinoma, Areca nut, Gutka

\footnotetext{
* Correspondence: dramirkhan04@gmail.com

${ }^{3}$ Kandahar University, Kandahar, Afghanistan

Full list of author information is available at the end of the article
}

(c) The Author(s). 2018 Open Access This article is distributed under the terms of the Creative Commons Attribution 4.0 International License (http://creativecommons.org/licenses/by/4.0/), which permits unrestricted use, distribution, and reproduction in any medium, provided you give appropriate credit to the original author(s) and the source, provide a link to the Creative Commons license, and indicate if changes were made. The Creative Commons Public Domain Dedication waiver (http://creativecommons.org/publicdomain/zero/1.0/) applies to the data made available in this article, unless otherwise stated. 


\section{Background}

With a global incidence of 500,000 per annum, squamous cell carcinoma has been reported to be the most prevalent cancer of the oral cavity [1]. In South Asia, head and neck cancers are the third leading cause of cancer-related morbidity and mortality [2-4]. Approximately 90 to $95 \%$ of oral squamous cell carcinoma (SCC) shows varied degrees of epithelial dysplasia [5]. Molecular carcinogenesis of head and neck squamous cell carcinoma (HNSCC) is attributed to several cytogenetic alterations in oncogenes and receptors for growth factors including p53, p27, p16, cyclin D1, and epidermal growth factor receptor (EGFR) $[6,7]$. Cellular growth differentiation and proliferation rely on the growth factor-induced stimulation of the cellular processes. EGFR plays a substantial role in differentiation and proliferation of the mammalian cells [8]. Expression of EGFR in a number of epithelial cell tumors in humans has been well documented, and $80 \%$ of squamous cell carcinomas are marked by over-expression of EGFR, resulting in proliferation and differentiation of keratinocytes [9-11]. Squamous cell carcinomas of the head and neck exhibit a varying degree of behavior apropos of cellular growth rate, differentiation, and metastasis. In our setup, areca nut/gutka chewing has been asserted as a major risk factor attributable to the development of leukoplakia and subsequent SCC of oral cavity. In the era of personalized medicine, it is largely accepted that cancer therapy protocols should be devised in the light of tumor characteristics of loco-regional population.

Previous studies revealed that immunohistochemical over-expression of EGFR correlates with poor prognosis [12]; moreover, EGFR over-expression is considered as an attractive target for anti-EGFR therapy in various tumors. Therefore, in the present study, we studied the association of EGFR over-expression with unfavorable prognostic features including advanced tumor grade, tumor size, nodal metastasis, and recurrence status in our population.

\section{Methods}

This was a retrospective study conducted in the Department of Histopathology, Liaquat National Hospital from January 2008 till December 2013. The study duration was 7 years. One hundred fifteen cases of biopsy-proven squamous cell carcinoma were included in the study. All patients underwent radical excisions of cancer along with

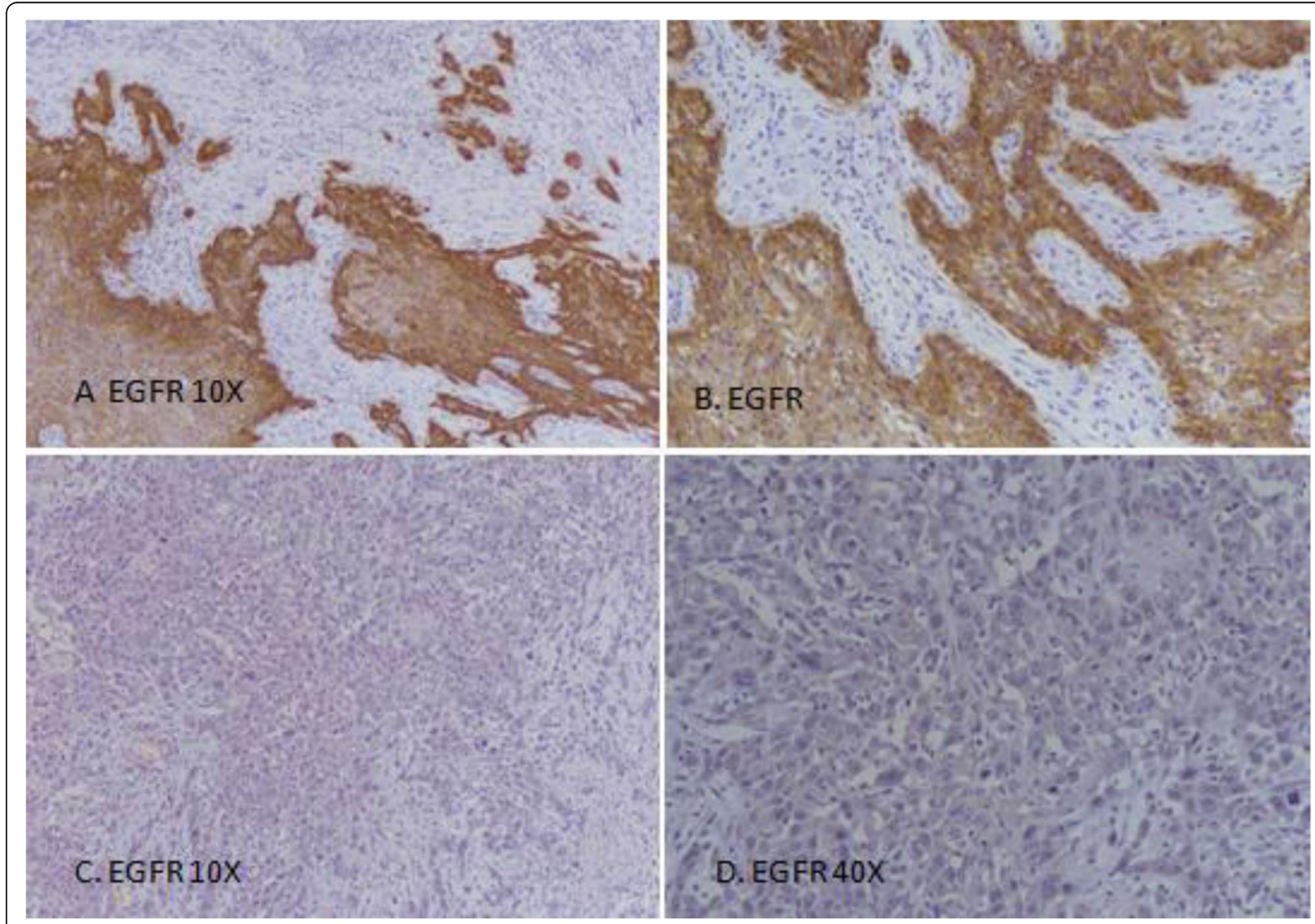

Fig. 1 EGFR expression in head and neck squamous cell carcinoma. a, b Positive EGFR expression 3+, > 70\% cells; c, d Negative EGFR expression 
Table 1 Clinico-pathologic features of squamous cell carcinoma head and neck $(n=115)$

\begin{tabular}{|c|c|}
\hline Characteristic & Frequency (\%) \\
\hline$\overline{\text { Age }(\text { years) }}{ }^{a}$ & $51.95 \pm 12.62$ \\
\hline \multicolumn{2}{|l|}{ Age groups } \\
\hline$\leq 30$ years & $4(3.5)$ \\
\hline $31-50$ years & $57(49.6)$ \\
\hline$>50$ years & $54(47)$ \\
\hline \multicolumn{2}{|l|}{ Gender } \\
\hline Male & 85 (73.9) \\
\hline Female & $30(26.1)$ \\
\hline \multicolumn{2}{|l|}{ History of pan $(n=44)$} \\
\hline Yes & $27(61.4)$ \\
\hline No & $17(38.6)$ \\
\hline \multicolumn{2}{|l|}{ History of smoking $(n=44)$} \\
\hline Yes & $4(9.1)$ \\
\hline No & $40(90.9)$ \\
\hline \multicolumn{2}{|l|}{ History of alcohol $(n=44)$} \\
\hline Yes & $1(2.3)$ \\
\hline No & $43(97.7)$ \\
\hline \multicolumn{2}{|l|}{ Location of tumor } \\
\hline Oral cavity & $79(68.7)$ \\
\hline Lip & $3(2.6)$ \\
\hline Tongue & $29(25.2)$ \\
\hline Soft palate & $4(3.5)$ \\
\hline Tumor size $(\mathrm{cm})^{a}$ & $3.21 \pm 1.74$ \\
\hline \multicolumn{2}{|l|}{ Tumor stage } \\
\hline $\mathrm{T} 1$ & $31(27)$ \\
\hline $\mathrm{T} 2$ & $54(47)$ \\
\hline $\mathrm{T} 3 / \mathrm{T} 4$ & $30(26.1)$ \\
\hline Depth of invasion $(\mathrm{cm})^{\mathrm{a}}$ & $1.11 \pm 0.74$ \\
\hline \multicolumn{2}{|l|}{ Depth of invasion } \\
\hline$<2 \mathrm{~cm}$ & $98(85.2)$ \\
\hline$\geq 2 \mathrm{~cm}$ & $17(14.8)$ \\
\hline \multicolumn{2}{|l|}{ Nodal stage } \\
\hline No & $63(54.8)$ \\
\hline N1 & $17(14.8)$ \\
\hline $\mathrm{N} 2 \mathrm{a}$ & $0(0)$ \\
\hline $\mathrm{N} 2 \mathrm{~b}$ & $31(27)$ \\
\hline $\mathrm{N} 2 \mathrm{C}$ & $3(2.6)$ \\
\hline N3 & $1(0.9)$ \\
\hline \multicolumn{2}{|l|}{ Extranodal extention } \\
\hline Not present & 85 (73.9) \\
\hline Present & $30(26.1)$ \\
\hline \multicolumn{2}{|l|}{ Histological subtypes } \\
\hline Non-keratinizing & $17(14.8)$ \\
\hline
\end{tabular}

Table 1 Clinico-pathologic features of squamous cell carcinoma head and neck ( $n=115)$ (Continued)

\begin{tabular}{ll}
\hline Characteristic & Frequency (\%) \\
\hline Keratinizing & $65(56.5)$ \\
Non-keratinizing with maturation & $33(28.7)$ \\
Histologic grade & \\
Grade-I & $31(27)$ \\
Grade-II & $71(61.7)$ \\
Grade-III & $13(11.3)$ \\
Lymphovascular invasion & \\
Not present & $114(99.1)$ \\
Present & $1(0.9)$ \\
Perineural invasion & \\
Not present & $99(86.1)$ \\
Present & $16(13.9)$ \\
Radiation $(n=45)$ & \\
Yes & $25(55.6)$ \\
No & $20(44.4)$ \\
Chemotherapy $(n=45)$ & \\
Yes & $24(53.3)$ \\
No & $21(46.7)$ \\
Recurrence $(n=45)$ & \\
Yes & \\
No & $22(48.9)$ \\
\hline Mean \pm SD &
\end{tabular}

neck dissection from level I to level V. The study was approved from research and ethical review committee of Liaquat National Hospital. Slides of all cases were retrieved from records of pathology department and reviewed by two surgical pathologists to determine tumor characteristics including histological type, grade, $\mathrm{T}$-stage, $\mathrm{N}$-stage, and perineural and lymphovascular invasion. Representative tissue blocks of all cases were selected for immunohistochemistry.

Clinical records of 45 patients were available. Many patients lost to follow-up or history of risk factors were not mentioned in patient records. Clinical records of these patients were reviewed from institutional records to evaluate patients' age, smoking, alcohol and gutka/ pan use history, history of radiation and chemotherapy, and recurrence status.

Immunohistochemistry

EGFR immunohistochemistry was done using DAKO EnVision method and DAKO Monoclonal Mouse Anti-human Epidermal growth factor Receptor (EGFR), clone $\mathrm{H} 11$ as per manufacturer recommendations. Both membranous and cytoplasmic staining for EGFR was evaluated. Intensity of staining was assorted into no staining $(0)$, weak $(1+)$, intermediate $(2+)$, and strong $(3+)$ while 
percentage of positively stained cells was counted. Intermediate to strong staining in $>10 \%$ of tumor cells was considered positive while weak to intermediate staining in $<10 \%$ of cancer cells was taken as focal positive (Fig. 1). Moreover, EGFR immunostaining was also categorized according to percentage of staining cells into different groups as shown in Table 2.

\section{Follow-up and recurrence}

Hospital file records were evaluated to determine recurrence status of the patients. Disease-free survival was defined as time from surgical resection till first recurrence, patient's death, or last medical follow-up. Overall survival was labeled as time from primary treatment till death or last follow-up. None of the patients received anti-EGFR therapy.

\section{Statistical analysis}

Statistical package for social sciences (SPSS 21) was adopted for data analysis. Mean and standard deviation were evaluated for quantitative variables. Frequency and percentage were calculated for qualitative variables. Chi-square was applied to determine association. Kaplan-Meier method was used to determine survival, while significance of difference between survival curves was evaluated using log-rank ratio. $P$ value of $\leq 0.05$ was taken as significant.

\section{Results}

Clinico-pathologic features of squamous cell carcinoma of the head and neck

Table 1 shows demographic characteristics of the studied population. Mean age of the patients was $51.95 \pm 12.62$. Majority of patients were males (73.9\%). History of addiction could only be evaluated in 44 patients out of whom 27 patients (61.4\%) revealed addicted with gutka/ pan. No appreciable addiction was noted with other factors like smoking or alcohol. The most common tumor location was the oral cavity (68.7\%). Majority of patients were found to be at tumor stage T2 (47\%). More than $2 \mathrm{~cm}$ tumor depth was noted in $17 \%$ of cases. Nodal metastasis was seen in $45.2 \%$ of cases, while majority of tumors were keratinizing subtype (56.5\%) and of grade II (61.7\%). Adjuvant radiation and chemotherapy were given in 53.3 and $51.1 \%$ of cases respectively. $51.1 \%$ of cases recurred after primary treatment.

\section{EGFR immunohistochemistry and association with clinico- pathologic parameters}

In our study, 52 cases $(45.2 \%)$ of head and neck SCC were positive and 10 cases (8.7\%) were focal positive for EGFR expression, while 53 cases (46.1\%) were negative for EGFR expression. Figure 1 shows percentage of EGFR expression in head and neck squamous cell carcinoma. High EGFR expression $(>70 \%)$ was noted in $6.1 \%$ ( 7 cases), while $12.2 \%$ ( 14 cases) and $26.1 \%$ (30

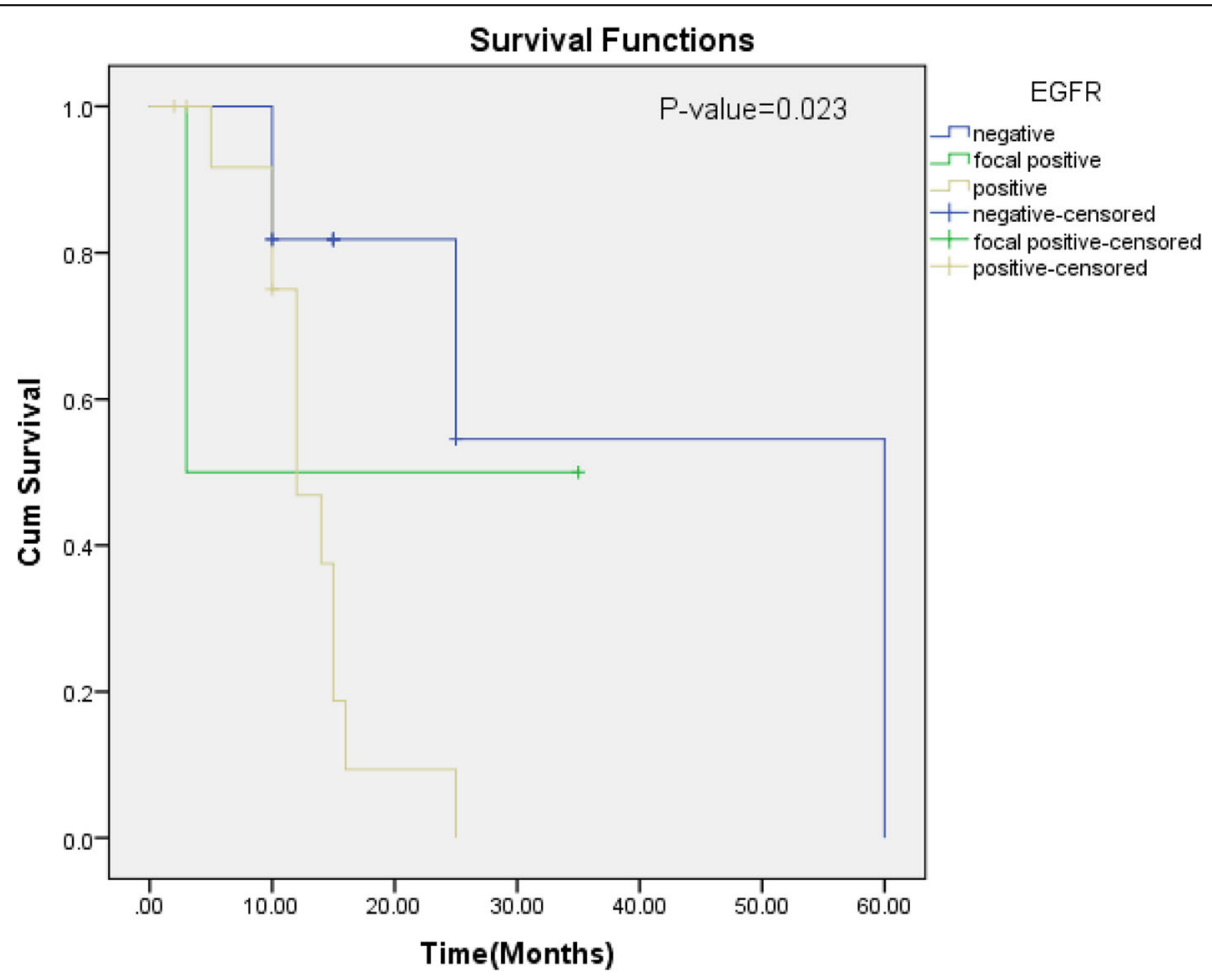

Fig. 2 Kaplan-Meier for EGFR over-expression (disease-free survival) 
Table 2 Association of EGFR expression categories (percentage) with clinico-pathologic parameters of head and neck squamous cell carcinoma

\begin{tabular}{|c|c|c|c|c|c|c|}
\hline & \multicolumn{5}{|l|}{$n(\%)$} & \multirow[t]{2}{*}{$P$ value } \\
\hline & $\leq 10 \%(n=64)$ & $11-50 \%(n=30)$ & $51-70 \%(n=14)$ & $>70 \%(n=7)$ & Total $(n=115)$ & \\
\hline \multicolumn{7}{|l|}{ Age group } \\
\hline$\leq 30$ years & $1(1.6)$ & $1(3.3)$ & $2(14.3)$ & $0(0)$ & $4(3.5)$ & \multirow[t]{3}{*}{0.334} \\
\hline $31-50$ years & $34(53.1)$ & $12(40)$ & $7(50)$ & $4(57.1)$ & $57(49.6)$ & \\
\hline$>50$ years & $29(45.3)$ & $17(56.7)$ & $5(35.7)$ & $3(42.9)$ & $54(47)$ & \\
\hline \multicolumn{7}{|l|}{ Gender } \\
\hline Male & $45(70.3)$ & $24(80)$ & $11(78.6)$ & $5(71.4)$ & $85(73.9)$ & \multirow[t]{2}{*}{0.793} \\
\hline Female & $19(29.7)$ & $6(20)$ & $3(21.4)$ & $2(28.6)$ & $30(26.1)$ & \\
\hline \multicolumn{7}{|l|}{ History of pan $(n=44)$} \\
\hline Yes & $14(56)$ & $7(70)$ & $2(66.7)$ & $4(66.7)$ & $27(61.4)$ & \multirow[t]{2}{*}{0.917} \\
\hline No & $11(44)$ & $3(30)$ & $1(33.3)$ & $2(33.3)$ & 17 (38.6) & \\
\hline \multicolumn{7}{|l|}{ History of smoking $(n=44)$} \\
\hline Yes & $4(16)$ & $0(0)$ & $0(0)$ & $0(0)$ & $4(9.1)$ & \multirow[t]{2}{*}{0.497} \\
\hline No & $21(84)$ & $10(100)$ & $3(100)$ & $6(100)$ & $40(90.9)$ & \\
\hline \multicolumn{7}{|l|}{ History of alcohol $(n=44)$} \\
\hline Yes & $0(0)$ & $1(10)$ & $0(0)$ & $0(0)$ & $1(2.3)$ & \multirow[t]{2}{*}{0.432} \\
\hline No & $25(100)$ & $9(90)$ & $3(100)$ & $6(100)$ & $43(97.7)$ & \\
\hline \multicolumn{7}{|l|}{ Location of tumor } \\
\hline Oral cavity & $47(73.4)$ & $18(60)$ & $10(71.4)$ & $4(57.1)$ & $79(68.7)$ & \multirow[t]{4}{*}{0.369} \\
\hline Lip & $1(1.6)$ & $1(3.3)$ & $1(7.1)$ & $0(0)$ & $3(2.6)$ & \\
\hline Tongue & $12(18.8)$ & $11(36.7)$ & $3(21.4)$ & $3(42.9)$ & $29(25.2)$ & \\
\hline Soft palate & $4(6.3)$ & $0(0)$ & $0(0)$ & $0(0)$ & $4(3.5)$ & \\
\hline \multicolumn{7}{|l|}{ Tumor stage } \\
\hline $\mathrm{T} 1$ & $14(21.9)$ & $13(43.3)$ & $2(14.3)$ & $2(28.6)$ & $31(27)$ & \multirow[t]{3}{*}{0.013} \\
\hline $\mathrm{T} 2$ & $38(59.4)$ & $10(33.3)$ & $4(28.6)$ & $2(28.6)$ & $54(47)$ & \\
\hline $\mathrm{T} 3 / \mathrm{T} 4$ & $12(18.8)$ & $7(23.3)$ & $8(57.1)$ & $3(42.9)$ & $30(26.1)$ & \\
\hline \multicolumn{7}{|l|}{ Depth of invasion } \\
\hline$<2 \mathrm{~cm}$ & $54(84.4)$ & $28(93.3)$ & $10(71.4)$ & $6(85.7)$ & $98(85.2)$ & \multirow[t]{2}{*}{0.271} \\
\hline$\geq 2 \mathrm{~cm}$ & $10(15.6)$ & $2(6.7)$ & $4(28.6)$ & $1(14.3)$ & $17(14.8)$ & \\
\hline \multicolumn{7}{|l|}{ Nodal stage } \\
\hline No & $35(54.7)$ & $20(66.7)$ & $4(28.6)$ & $4(57.1)$ & $63(54.8)$ & \multirow[t]{6}{*}{0.082} \\
\hline N1 & $11(17.2)$ & $2(6.7)$ & $4(28.6)$ & $0(0)$ & $17(14.8)$ & \\
\hline $\mathrm{N} 2 \mathrm{a}$ & $0(0)$ & $0(0)$ & $0(0)$ & $0(0)$ & $0(0)$ & \\
\hline $\mathrm{N} 2 \mathrm{~b}$ & $17(26.6)$ & $6(20)$ & $6(42.9)$ & $2(28.6)$ & $31(27)$ & \\
\hline $\mathrm{N} 2 \mathrm{C}$ & $0(0)$ & $2(6.7)$ & $0(0)$ & $1(14.3)$ & $3(2.6)$ & \\
\hline N3 & $1(1.6)$ & $0(0)$ & $0(0)$ & $0(0)$ & $1(0.9)$ & \\
\hline \multicolumn{7}{|l|}{ Extranodal extention } \\
\hline Not present & $51(79.7)$ & $23(76.7)$ & $7(50)$ & $4(57.1)$ & $85(73.9)$ & \multirow[t]{2}{*}{0.089} \\
\hline Present & $13(20.3)$ & $7(23.3)$ & $7(50)$ & $3(42.9)$ & $30(26.1)$ & \\
\hline \multicolumn{7}{|l|}{ Histological subtypes } \\
\hline Non-keratinizing & $10(15.6)$ & $3(10)$ & $3(21.4)$ & $1(14.3)$ & $17(14.8)$ & \multirow[t]{3}{*}{0.527} \\
\hline Keratinizing & $37(57.8)$ & $20(66.7)$ & $5(35.7)$ & $3(42.9)$ & $65(56.5)$ & \\
\hline Non-keratinizing with maturation & 17 (26.6) & $7(23.3)$ & $6(42.9)$ & $3(42.9)$ & $3(28.7)$ & \\
\hline
\end{tabular}


Table 2 Association of EGFR expression categories (percentage) with clinico-pathologic parameters of head and neck squamous cell carcinoma (Continued)

\begin{tabular}{|c|c|c|c|c|c|c|}
\hline & $n(\%)$ & & & & & $P$ value \\
\hline & $\leq 10 \%(n=64)$ & $11-50 \%(n=30)$ & $51-70 \%(n=14)$ & $>70 \%(n=7)$ & Total $(n=115)$ & \\
\hline Histologic grad & & & & & & \\
\hline Grade-l & $20(31.3)$ & $9(30)$ & $1(7.1)$ & $1(14.3)$ & $31(27)$ & 0.592 \\
\hline Grade-II & $37(57.8)$ & $18(60)$ & $11(78.6)$ & $5(71.4)$ & $71(61.7)$ & \\
\hline Grade-III & $7(10.9)$ & $3(10)$ & $2(14.3)$ & $1(14.3)$ & $13(11.3)$ & \\
\hline Lymphovascula & & & & & & \\
\hline Not present & $63(98.4)$ & $30(100)$ & $14(100)$ & $7(100)$ & $114(99.1)$ & 1.000 \\
\hline Present & $1(1.6)$ & $0(0)$ & $0(0)$ & $0(0)$ & $1(0.9)$ & \\
\hline Perineural invas & & & & & & \\
\hline Not present & $57(89.1)$ & $26(86.7)$ & $12(85.7)$ & $4(57.1)$ & 99 (86.1) & 0.159 \\
\hline Present & $7(10.9)$ & $4(13.3)$ & $2(14.3)$ & $3(42.9)$ & 16 (13.9) & \\
\hline Radiation $(n=4$ & & & & & & \\
\hline Yes & $17(65.4)$ & $5(50)$ & $0(0)$ & $3(50)$ & 25 (55.6) & 0.174 \\
\hline No & $9(34.6)$ & $5(50)$ & $3(100)$ & $3(50)$ & $20(44.4)$ & \\
\hline Chemotherapy & & & & & & \\
\hline Yes & $17(65.4)$ & $4(40)$ & $0(0)$ & $3(50)$ & $24(53.3)$ & 0.128 \\
\hline No & $9(34.6)$ & $6(60)$ & $3(100)$ & $3(50)$ & $21(46.7)$ & \\
\hline
\end{tabular}

Chi-square test was applied

$P$ value $\leq 0.05$ was considered as significant

cases) revealed $51-70 \%$ and $11-50 \%$ EGFR expression respectively. On the basis of intensity, strong EGFR expression was noted in $13.9 \%$ (16 cases) while $16.5 \%$ (19 cases) and 23.5\% (27 cases) revealed intermediate and weak EGFR expression respectively. Association of EGFR expression intensity and percentage revealed significant association of EGFR expression with tumor stage, while no significant association was noted with other prognostic parameters and risk factors (Tables 2 and 3). Significant association of EGFR expression was noted with recurrence status of the patients (Fig. 2).

\section{Discussion}

Immunohistochemical staining of 115 carcinomas of the squamous cell origin from the head and neck biopsies was carried out to find out the frequency of EGFR expression in head and neck SCC of our population and to determine an association of EGFR over-expression with unfavorable prognostic features including advanced tumor grade, tumor size, nodal metastasis, and recurrence status in our population. $45.2 \%$ of our cases revealed EGFR over-expression, and significant association of EGFR was noted with tumor stage and disease-free survival, which are among the most important prognostic factors in head and neck SCC.

High expression of EGFR in head and neck SSC has been reported by previous studies [7]. In a similar study conducted by Sarkis et al., the EGFR immunostaining was positive in $87.5 \%$ of the cases [8]. Likewise, a high expression of EGFR $73.42 \%$ was found in another study conducted by Laimer et. al. Moreover, $92.3 \%$ of cases were positive for EGFR staining in the study conducted by Hiraishi et.al [13]. As a consequence of inconsistency in methods of evaluation of EGFR, incongruity exists between studies reporting EGFR as a prognostic marker of squamous cell carcinoma. Over-expression of EGFR correlates with aggressive tumor behavior and decreased life expectancy [14]. In our study, we found that $45.2 \%$ of cases of SCC of head and neck showed positive EGFR staining, and small numbers of cases (8.7\%) were focal positive, whereas $46.1 \%$ of cases showed negative EGFR staining. Comparison with other studies reveals that EGFR expression is relatively low in our population compared the reported data.

In an antecedent qualitative literature review conducted by Piccirillo et al., no significant association between age, gender, tumor location, grade and lymph node involvement, and prognosis of the disease was expressed [15]; however, these tumor characteristics play a meaningful role in disease management. Similarly, Grandis et al. expressed that no significant association was found between these clinico-pathologic characteristics of tumor with regard to meaningful clinical outcomes [16]. Hence, these characteristics are regarded as inefficient predictors of disease outcome, but frequently considered in designing personalized therapeutic regimes. In congruence with these previous studies, we found no 
Table 3 Association of EGFR expression intensity with clinico-pathologic parameters of head and neck squamous cell carcinoma

\begin{tabular}{|c|c|c|c|c|c|c|}
\hline & \multicolumn{5}{|l|}{$n(\%)$} & \multirow{2}{*}{$\begin{array}{l}P \\
\text { value }\end{array}$} \\
\hline & No intensity $(n=53)$ & Weak $(n=27)$ & Intermediate $(n=19)$ & Strong $(n=16)$ & Total $(n=115)$ & \\
\hline \multicolumn{7}{|l|}{ Age group } \\
\hline$\leq 30$ years & $1(1.9)$ & $0(0)$ & $1(5.3)$ & $2(12.5)$ & $4(3.5)$ & \multirow[t]{3}{*}{0.447} \\
\hline $31-50$ years & $27(50.9)$ & $12(44.4)$ & $10(52.6)$ & $8(50)$ & $57(49.6)$ & \\
\hline$>50$ years & $25(47.2)$ & $15(55.6)$ & $8(42.1)$ & $6(37.5)$ & $54(47)$ & \\
\hline \multicolumn{7}{|l|}{ Gender } \\
\hline Male & $37(69.8)$ & $21(77.8)$ & $16(84.2)$ & $11(68.8)$ & $85(73.9)$ & \multirow[t]{2}{*}{0.628} \\
\hline Female & $16(30.2)$ & $6(22.2)$ & $3(15.9)$ & $5(31.3)$ & $30(26.1)$ & \\
\hline \multicolumn{7}{|l|}{ History of pan $(n=44)$} \\
\hline Yes & $11(55)$ & $6(66.7)$ & $5(62.5)$ & $5(71.4)$ & $27(61.4)$ & \multirow[t]{2}{*}{0.915} \\
\hline No & $9(45)$ & $3(33.3)$ & $3(37.5)$ & $2(28.6)$ & $17(38.6)$ & \\
\hline \multicolumn{7}{|l|}{ History of smoking $(n=44)$} \\
\hline Yes & $4(20)$ & $0(0)$ & $0(0)$ & $0(0)$ & $4(9.1)$ & \multirow[t]{2}{*}{0.251} \\
\hline No & $16(80)$ & $9(100)$ & $8(100)$ & $7(100)$ & $40(90.9)$ & \\
\hline \multicolumn{7}{|l|}{ History of alcohol $(n=44)$} \\
\hline Yes & $0(0)$ & $1(11.1)$ & $0(0)$ & $0(0)$ & $1(2.3)$ & \multirow[t]{2}{*}{0.545} \\
\hline No & $20(100)$ & $8(88.9)$ & $8(100)$ & $7(100)$ & $43(97.7)$ & \\
\hline \multicolumn{7}{|l|}{ Location of tumor } \\
\hline Oral cavity & $38(71.7)$ & $19(70.4)$ & $12(63.2)$ & $10(62.5)$ & $79(68.7)$ & \multirow[t]{4}{*}{0.814} \\
\hline Lip & $1(1.9)$ & $1(3.7)$ & $0(0)$ & $1(6.3)$ & $3(2.6)$ & \\
\hline Tongue & $11(20.8)$ & $6(22.2)$ & $7(36.8)$ & $5(31.3)$ & $29(25.2)$ & \\
\hline Soft palate & $3(5.7)$ & $1(3.7)$ & $0(0)$ & $0(0)$ & $4(3.5)$ & \\
\hline \multicolumn{7}{|l|}{ Tumor stage } \\
\hline $\mathrm{T} 1$ & $12(22.6)$ & $7(25.9)$ & $9(47.4)$ & $3(18.8)$ & $31(27)$ & \multirow[t]{3}{*}{0.003} \\
\hline $\mathrm{T} 2$ & $33(62.3)$ & $13(48.1)$ & $5(26.3)$ & $3(18.8)$ & $54(47)$ & \\
\hline $\mathrm{T} 3 / \mathrm{T} 4$ & $8(15.1)$ & $7(25.9)$ & $5(26.3)$ & $10(62.5)$ & $30(26.1)$ & \\
\hline \multicolumn{7}{|l|}{ Tumor depth } \\
\hline$<2 \mathrm{~cm}$ & $46(86.8)$ & $22(81.5)$ & $18(94.7)$ & $12(75)$ & $98(85.2)$ & \multirow[t]{2}{*}{0.377} \\
\hline$\geq 2 \mathrm{~cm}$ & $7(13.2)$ & $5(18.5)$ & $1(5.3)$ & $4(25)$ & $17(14.8)$ & \\
\hline \multicolumn{7}{|l|}{ Nodal stage } \\
\hline No & $30(56.6)$ & $14(51.9)$ & $13(68.4)$ & $6(37.5)$ & $63(54.8)$ & \multirow[t]{6}{*}{0.433} \\
\hline N1 & $10(18.9)$ & $3(11.1)$ & $1(5.3)$ & $3(18.8)$ & $17(14.8)$ & \\
\hline $\mathrm{N} 2 \mathrm{a}$ & $0(0)$ & $0(0)$ & $0(0)$ & $0(0)$ & $0(0)$ & \\
\hline $\mathrm{N} 2 \mathrm{~b}$ & $12(22.6)$ & $8(29.6)$ & $5(26.3)$ & $6(37.5)$ & $31(27)$ & \\
\hline $\mathrm{N} 2 \mathrm{C}$ & $0(0)$ & $2(7.4)$ & $0(0)$ & $1(6.3)$ & $3(2.6)$ & \\
\hline N3 & $1(1.9)$ & $0(0)$ & $0(0)$ & $0(0)$ & $1(0.9)$ & \\
\hline \multicolumn{7}{|l|}{ Extranodal extention } \\
\hline Not present & $43(81.1)$ & $19(70.4)$ & $14(73.7)$ & $9(56.3)$ & 85 (73.9) & \multirow[t]{2}{*}{0.236} \\
\hline Present & $10(18.9)$ & $8(29.6)$ & $5(26.3)$ & $7(43.8)$ & $30(26.1)$ & \\
\hline \multicolumn{7}{|l|}{ Histological subtypes } \\
\hline Non-keratinizing & $8(15.1)$ & $3(11.1)$ & $3(15.8)$ & $3(18.8)$ & $17(14.8)$ & \multirow[t]{3}{*}{0.823} \\
\hline Keratinizing & $33(62.3)$ & $15(55.6)$ & $10(52.6)$ & $7(43.8)$ & $65(56.5)$ & \\
\hline Non-keratinizing with maturation & $12(22.6)$ & $9(33.3)$ & $6(31.6)$ & $6(37.5)$ & $33(28.7)$ & \\
\hline
\end{tabular}


Table 3 Association of EGFR expression intensity with clinico-pathologic parameters of head and neck squamous cell carcinoma (Continued)

\begin{tabular}{|c|c|c|c|c|c|c|}
\hline & \multicolumn{5}{|l|}{$n(\%)$} & \multirow{2}{*}{$\begin{array}{l}P \\
\text { value }\end{array}$} \\
\hline & No intensity $(n=53)$ & Weak $(n=27)$ & Intermediate $(n=19)$ & Strong $(n=16)$ & Total $(n=115)$ & \\
\hline Grade-I & $19(35.8)$ & $7(25.9)$ & $4(21.1)$ & $1(6.3)$ & $31(27)$ & 0.281 \\
\hline Grade-II & $27(50.9)$ & $18(66.7)$ & $13(68.4)$ & $13(81.3)$ & $71(61.7)$ & \\
\hline Grade-III & $7(13.2)$ & $2(7.4)$ & $2(10.5)$ & $2(12.5)$ & $13(11.3)$ & \\
\hline \multicolumn{7}{|c|}{ Lymphovascular invasion } \\
\hline Not present & $52(98.1)$ & $27(100)$ & $19(100)$ & $16(100)$ & $114(99.1)$ & 1.000 \\
\hline Present & $1(1.9)$ & $0(0)$ & $0(0)$ & $0(0)$ & $1(0.9)$ & \\
\hline \multicolumn{7}{|c|}{ Perineural invasion } \\
\hline Not present & 48 (90.6) & $23(85.2)$ & $15(78.9)$ & $13(81.3)$ & $99(86.1)$ & 0.493 \\
\hline Present & $5(9.4)$ & $4(14.8)$ & $4(21.1)$ & $3(18.8)$ & $16(13.9)$ & \\
\hline \multicolumn{7}{|c|}{ Radiation $(n=45)$} \\
\hline Yes & $12(60)$ & $7(70)$ & $4(50)$ & $2(28.6)$ & $25(55.6)$ & 0.366 \\
\hline No & $8(40)$ & $3(30)$ & $4(50)$ & $5(71.4)$ & $20(44.4)$ & \\
\hline \multicolumn{7}{|c|}{ Chemotherapy $(n=45)$} \\
\hline Yes & $12(60)$ & $6(60)$ & $4(50)$ & $2(28.6)$ & $24(53.3)$ & 0.513 \\
\hline No & $8(40)$ & $4(40)$ & $4(50)$ & $5(71.4)$ & $21(46.7)$ & \\
\hline
\end{tabular}

Chi-square test was applied

$P$ value $\leq 0.05$ considered as significant

significant association between EGFR over-expression with many clinico-pathologic characteristics including age, gender, tumor depth, nodal stage, and histological stage in our study; however, significant association was noted with tumor stage. Hiraishi et al. in a study involving 52 cases of oral SCC revealed significant association of EGFR over-expression with tumor invasion; however, association with other prognostic parameters was not found.

Another role of IHC expression of EGFR resides in its ability to differentiate between healthy/hyperplastic and diseased/dysplastic (premalignant) proliferative changes, as many authors found a significantly high expression of EGFR in premalignant squamous mucosa compared to hyperplastic/non-premalignant squamous epithelium $[17,18]$. Similar to our study, Srivastava et al. also did not found a significant association of various risk factors with EGFR expression [19]. In contrast to our study, Panday et al., in a study involving 24 locally advanced HNSCC cases, did not found any significant association of EGFR expression with disease-free survival in patients taking neoadjuvant chemotherapy [20]. Similarly, Kumar et al. suggested that EGFR expression did not predict response to neoadjuvant chemotherapy [21]. On the other hand, adjuvant anti-EGFR therapy (e.g., Cetuximab) significantly improves survival in patients with advanced HNSCC [22]. Zafar et al. did not found any significant association of EGFR with tumor grade; however, association with other prognostic factors was not tested in their study [23].
We did not perform molecular studies in our cases (limitations of the study) because, for the use of anti-EGFR-targeted therapy, it is widely accepted that only IHC EGFR expression is not enough for patient selection that may benefit from EGFR-directed therapy. The reason behind that is IHC EGFR expression does not necessarily correlate with underlying gene amplification. Bermardes et al. reported no significant association of EGFR over-expression with gene amplification by FISH or CISH. In their study, although IHC over-expression of EGFR was noted in $53.8 \%$ of cases, gene amplification was seen in only 5.8 and $15.4 \%$ by $\mathrm{CISH}$ and FISH respectively [24].

\section{Conclusion}

We found a significant association of EGFR expression with tumor stage and disease-free survival, which are the most important prognostic factors in head and neck squamous cell carcinoma; therefore, EGFR expression can be used as a prognostic biomarker in head and neck squamous cell carcinoma. On the other hand, we suggest that molecular studies should be performed in squamous cell carcinoma of head and neck in our setup to identify patients that can benefit from anti-EGFR therapy.

\section{Acknowledgements}

We gratefully acknowledge all staff members of Pathology, Liaquat National Hospital, Karachi, Pakistan, for their help and cooperation.

Availability of data and materials

Please contact author Atif Ali Hashmi (doc_atif2005@yahoo.com) for data requests. 


\section{Authors' contributions}

$\mathrm{AAH}$ and $\mathrm{ZFH}$ are the main authors of the manuscript, and they made substantial contributions to the conception and design of the study. SA, MI, and EYK were involved in the requisition of data. SN, NF, AK, and MME were involved in the analysis of the data and revision of the manuscript. All authors read, revised, and approved the manuscript.

\section{Ethics approval and consent to participate}

The Ethics committee of Liaquat National Hospital, Karachi, Pakistan, approved the study. Written informed consent was obtained from the patients for the participation

\section{Consent for publication}

Not applicable

\section{Competing interests}

The authors declare that they have no competing interests.

\section{Publisher's Note}

Springer Nature remains neutral with regard to jurisdictional claims in published maps and institutional affiliations.

\section{Author details}

${ }^{1}$ Liaquat National Hospital and Medical College, Karachi, Pakistan. ${ }^{2}$ Shaheed Zulfiqar Ali Institute of Science and Technology, Karachi, Pakistan. ${ }^{3}$ Kandahar University, Kandahar, Afghanistan. ${ }^{4}$ Brown University, Providence, RI, USA.

\section{Received: 15 February 2018 Accepted: 22 June 2018}

\section{Published online: 28 June 2018}

\section{References}

1. Fernández A, Fernández J, Marshall M, Martínez R, Niklander S, Haidar ZS Difference in EGFR expression and mean vascular density in normal oral mucosa, oral epithelial dysplasia and oral squamous cell carcinoma. Journal of Oral Research. 2017:6(2):39-45.

2. Gupta N, Gupta R, Acharya AK, Patthi B, Goud V, Reddy S, Garg A, Singla A Changing Trends in oral cancer-a global scenario. Nepal Journal of Epidemiology. 2017;6(4):613-9.

3. Bhayekar PD, Gaopande VL, Joshi AR, Jadhav AB. Immunohistochemical study of p53, Ki-67, epidermal growth factor receptor, and sex-determining region Y-box 2 in squamous cell carcinoma of tongue. BLDE University Journal of Health Sciences. 2016;1 (2):102.

4. Naz S, Salah K, Khurshid A, Hashmi AA, Faridi N. Head and neck squamous cell carcinoma - comparative evaluation of pathological parameters in young and old patients. Asian Pac J Cancer Prev. 2015;16(9):4061-3.

5. Motta RD, Zettler CG, Cambruzzi E, Jotz GP, Berni RB. Ki-67 and p53 correlation prognostic value in squamous cell carcinomas of the oral cavity and tongue. Braz J Otorhinolaryngol. 2009;75(4):544-9.

6. Sozzi G, Miozzo M, Tagliabue E, Calderone C, Lombardi L, Pilotti S, Pastorino U, Pierotti MA, Della Porta G. Cytogenetic abnormalities and overexpression of receptors for growth factors in normal bronchial epithelium and tumor samples of lung cancer patients. Cancer Res. 1991;51(1):400-4.

7. Xia W, Lau YK, Zhang HZ, Xiao FY, Johnston DA, Liu AR, Li L, Katz RL, Hung MC. Combination of EGFR, HER-2/neu, and HER-3 is a stronger predictor for the outcome of oral squamous cell carcinoma than any individual family members. Clin Cancer Res. 1999;5(12):4164-74.

8. Laimer K, Spizzo G, Gastl G, Obrist P, Brunhuber T, Fong D, Barbieri V, Jank S, Doppler W, Rasse M, Norer B. High EGFR expression predicts poor prognosis in patients with squamous cell carcinoma of the oral cavity and oropharynx: a TMA-based immunohistochemical analysis. Oral Oncol. 2007;43:193-8. https://doi.org/10.1016/j.oraloncology.2006.02.009.

9. Sarkis SA, Abdullah BH, Majeed BA, Talabani NG. Immunohistochemical expression of epidermal growth factor receptor (EGFR) in oral squamous cell carcinoma in relation to proliferation, apoptosis, angiogenesis and lymphangiogenesis. Head Neck Oncol. 2010;2(1):13.

10. Christensen ME, Therkildsen MH, Hansen BL, Albeck H, Hansen GN, Bretlau P. Epidermal growth factor receptor expression on oral mucosa dysplastic epithelia and squamous cell carcinomas. Eur Arch Otorhinolaryngol. 1992;249(5):243-7.

11. Kalyankrishna S, Grandis JR. Epidermal growth factor receptor biology in head and neck cancer. J Clin Oncol. 2006 Jun 10;24(17):2666-72.
12. Ulanovski D, Stern Y, Roizman P, Shpitzer T, Popovtzer A, Feinmesser R. Expression of EGFR and Cerb-B2 as prognostic factors in cancer of the tongue. Oral Oncol. 2004;40(5):532-7.

13. Hiraishi Y, Wada T, Nakatani K, Negoro K, Fujita S. Immunohistochemical expression of EGFR and p-EGFR in oral squamous cell carcinomas. Pathol Oncol Res. 2006;12(2):87-91.

14. Arteaga $\mathrm{CL}$. Epidermal growth factor receptor dependence in human tumors: more than just expression? Oncologist. 2002;7(Supplement 4):31-9.

15. Piccirillo JF, Feinstein AR. Clinical symptoms and comorbidity: significance for the prognostic classification of cancer. Cancer. 1996;77(5):834-42.

16. Grandis JR, Melhem MF, Gooding WE, Day R, Holst VA, Wagener MM, Drenning SD, Tweardy DJ. Levels of TGF-a and EGFR protein in head and neck squamous cell carcinoma and patient survival. JNCl. 1998 Jun 3;90(11):824-32.

17. Jyothi Meka N, Ugrappa S, Velpula N, Kumar S, Naik Maloth K, Kodangal S, Ch L, Goyal S. Quantitative immunoexpression of EGFR in oral potentially malignant disorders: oral leukoplakia and oral submucous fibrosis. J Dent Res Dent Clin Dent Prospects. 2015 Summer;9(3):166-74.

18. Kobayashi H, Kumagai K, Gotoh A, Eguchi T, Yamada H, Hamada Y, Suzuki S, Suzuki R. Upregulation of epidermal growth factor receptor 4 in oral leukoplakia. Int J Oral Sci. 2013;5(1):14-20.

19. Srivastava VG, Kumar M, Chaturvedi TP, Pandey M. EGFR Over-expression in Head and Neck Squamous Carcinoma \& it's correlation with etiological factors like alcohol and tobacco. World J Pathol. 2016;5:3.

20. Pandey M, Kannepali KK, Dixit R, Kumar M. Effect of neoadjuvant chemotherapy and its correlation with HPV status, EGFR, Her-2-neu, and GADD45 expression in oral squamous cell carcinoma. World J Surg Oncol. 2018;16(1):20. https://doi.org/10.1186/s12957-018-1308-7.

21. Kumar A, Kumar M, Dixit R, Jaiswal R, Srivastava V, Pandey M. Presence of Human papilloma virus and EGFR expression does not predict response to Neoadjuvant chemotherapy in oral cancer. World Journal of Surgical Medical and Radiat Oncol. 2012:1:103-10.

22. Sundvall M, Karrila A, Nordberg J, Grénman R, Elenius K. EGFR targeting drugs in the treatment of head and neck squamous cell carcinoma. Expert Opin Emerg Drugs. 2010;15(2):185-201

23. Zafar M, Hashmi SN, Faisal MJ, Ahmed R, Ali SS. Immunohistochemica expression of epidermal growth factor receptor in head and neck squamous cell carcinoma. J Coll Physicians Surg Pak. 2017:27(4):209-12.

24. Bernardes VF, Gleber-Netto FO, de Sousa SF, Rocha RM, de Aguiar MCF. EGFR status in oralsquamous cell carcinoma: comparing immunohistochemistry, FISH and CISH detection in a case series study. BMJ Open. 2013:3(1):e002077.

Ready to submit your research? Choose BMC and benefit from

- fast, convenient online submission

- thorough peer review by experienced researchers in your field

- rapid publication on acceptance

- support for research data, including large and complex data types

- gold Open Access which fosters wider collaboration and increased citations

- maximum visibility for your research: over $100 \mathrm{M}$ website views per year

At BMC, research is always in progress.

Learn more biomedcentral.com/submissions 